\title{
Cvetka Hedžet Tóth
}

\section{Anamnetični um}

Ključne besede: anamnetični um, mnemosyne, upanje, utopija, metafizika

DOI: $10.4312 /$ ars.12.2.99-114

\section{Dialektična teorija družbe}

Zakaj v celotni Adornovi misli in nikakor ne samo v sociologiji tolikšen poudarek na družbi, na družbenem? V svojem 3. predavanju Uvoda v sociologijo Adorno sam opozarja, »da osrednji pojem sociologije, torej tisti, ki bi ga danes številni sociologi najraje vrgli stran, je pojem družbe«, in kakor koli že: sociologija »vendar pomeni logos o societas, se pravi spoznanje ali vednost o družbi«. (Adorno, 2016, 48) Že v svojem času je Adorno o pojmu družbe ugotavljal, da »cela vrsta sociologov meni, da ga ni več mogoče uporabljati«. (Adorno, 2016, 53) Tako v frankfurtski šoli kot v Adornovi misli je gotovo ena najpogosteje rabljenih besede gotovo beseda družba. Kako razumeti to dejstvo, še posebej danes, ko že do obsedenosti govorimo predvsem o kulturi, vsaj kar se tiče družboslovja in humanistike?

S tem smo zdaj na terenu frankfurtske šole in ne odrekamo se temu izrazu, čeprav je pogosteje rabljen izraz kritična teorija oziroma kar »kritična teorija družbe, katere prototip je Marxova teorija družbe«, (Adorno, 2016, 254) poudarja Adorno v Uvodu $v$ sociologijo $\mathrm{v}$ svojem zadnjem predavanju (11. 7. 1968) in torej samo leto pred svojo smrtjo spet opozarja na trajno aktualnost Marxove misli v svoji teoriji. Kritična teorija družbe briše stroge meje med tradicionalnimi disciplinami, med humanistiko in družboslovjem še posebej. Skratka, pred nami je zgledna interdisciplinarnost, ki humanistiko samo poglablja in krepi.

Albrecht Wellmer je v svojem prispevku Pomen frankfurtske šole danes opozoril, da frankfurtska šola »ni bila šola, ampak kolektivni in kooperativni projekt; projekt obnove in razvoja kritične teorije družbe«. (Wellmer, 1993, 224) Kot taka je oblikovala kritični vpogled $\mathrm{v}$ konzervativne in celo represivno-reakcionarne vidike nemške samovšečne kulture, kajti »kulturtregerstvo« - pri nas, Slovencih, so znani nacistični Kulturbund in njegovi kulturbundovci - je soodgovorno za marsikaj, kar se je dogajalo $\mathrm{v}$ času nacizma, in to vsekakor ni prenehalo po drugi vojni, ne pri nas in tudi ne znotraj Združene Evrope. 
Zelo dober poznavalec Adornove misli, nemški filozof Herbert Schnädelbach ugotavlja, da je beseda »družba« doživela vzpon v petdesetih letih zdaj že prejšnjega stoletja, in tukaj je treba upoštevati zelo svojevrstno usodo dveh besed, namreč kulture in družbe, kar - poudarjam - s svojim vplivom sega celo v naš, slovenski prostor.

Že v 19. stoletju je beseda kultura pomenila desničarsko usmerjenost, kajti sámo sociologijo so označevali za socialistično, med drugim tudi zgodovinar Heinrich von Treitschke (1834-1896). Skratka, po Schnädelbachu je beseda družba v Nemčiji pomenila »'levo' besedo«. (Schnädelbach, 2000, 111) Vemo, da je družba prostor med posameznikom in državo. Beseda »kultura « pa je bila privilegij konzervativcev, dobesedno prepoznavni znak zahodnjakov, varuhov "večnih vrednot«, in od konca 18. stoletja je veljala kot nasprotje civilizaciji, ki sicer materialno, tehnično »udomačevanje človeka« - lajša življenje ljudi, kultura pa pomeni etizacijo (Kant) in estetizacijo (Nietzsche) človeškega življenja. Kot opozarja Schnädelbach, se ta sicer trivialna delitev nadaljuje po drugi svetovni vojni, celo tako, da Goethe, operni abonma in drago rdeče vino pomenijo kulturo, železnica, kino in kokakola pa civilizacijo in tudi amerikanizacijo. (Gl. Hedžet Tóth, 2015, 123-128)

Kultura kot prestiž »desnih « seveda ni preprečila holokavsta in zdaj, v tej svojevrstni pojmovni delitvi na družbo in kulturo, Adorno ni mogel zapisati nič drugega kot misel, da »Auschwitz potrjuje filozofem o čisti identiteti kot smrti«. (Adorno, 1973, 355) To, kar se je žal zgodilo in kar se ni bi smelo nikdar zgoditi, se ne sme ponoviti nikdar več oziroma naj se ne bi ponovilo, je njegov povojni novi etični imperativ, ki apelira na novo obliko za preživetje: »Hitler je ljudem v stanju njihove nesvobode vsilil nov kategorični imperativ: njihovo mišljenje in ravnanje urediti tako, da se Auschwitz ne more ponoviti, da se ne more zgoditi nič podobnega. Ta imperativ je tako uporen proti njegovi utemeljitvi kot nekoč danost Kantovega. Bil bi zločin, če bi ga obravnavali diskurzivno: na njem je živo čutiti moment pridružitve k nravnemu. Živo zato, ker je praktični odpor do neznosne fizične bolečine tisti, kateremu so izpostavljeni posamezniki, tudi po individualnosti, kot duhovna refleksijska oblika pred izginotjem. Morala preživi le v materializmu brez olepšav.« (Adorno, 1973, 358)

Industrija smrti, ta strašni indeks neresnice o kulturi, po Adornu nemške še posebej, se je lahko zgodil v svetu, o katerem Adorno po drugi svetovni vojni ni mogel nič kaj drugega kot z Brechtovo pomočjo zapisati, da je vsa kultura »zgrajena iz pasjega govna. Leta pozneje, kot je to bilo zapisano, je Auschwitz neizpodbitno dokazal neuspeh kulture. Da se je nekaj takega lahko zgodilo sredi vse tradicije filozofije, umetnosti in razsvetljenskih znanosti, ne pove več kot samo to, da te, torej duh, človeka niso uspele dojeti in spremeniti.« (Adorno, 1973, 359) 
Še bolj odločen je s svojo mislijo v Prizmah, da je "pisati poezijo po Auschwitzu barbarsko«. (Adorno, 1977, 30) Ta misel, ki jo je zapisal leta 1949, objavljena je bila leta 1951, je sčasoma postala ena njegovih najbolj citiranih, saj je pomenila hud izziv, in kot kažejo številne zdajšnje interpretacije, gre za izziv, ki vse do danes ni izgubil svojega teoretskega naboja. Sam Adorno je v svojem predavanju leta 1962 izjavil: »Stavka, da je po Auschwitzu barbarsko še vedno pisati poezijo, ne želim omiliti; v njem je negativno izrečen impulz, ki navdihuje angažirano poezijo. (Adorno, 1974, 422) Habermas vedno znova opozarja na pomen teh Adornovih stališč in se v različnih kontekstih opira na Adornove analize - in v marsičem je Habermasova misel nadgradnja Adornove. (Gl. Hedžet Tóth, 2008, 369-434)

Toda ko gre za soočenje frankfurtske šole oziroma kritične teorije $z$ nekaterimi imeni iz nemške tradicije, se razhajanje med »družbo « in »kulturo« ne dogaja samo izključujoče in militantno; tako Albrecht Wellmer v tej zvezi podaja tole zanimivo ugotovitev: "Znotraj kulturne scene Zvezne republike Nemčije je bil Adorno mnogo več kot samo zelo opažen kritik in filozofski komentator; on je bil ta, ki je avtentičnost spet osvobodil iz reakcionarno okužene tradicije nemške kulture in ki je te tradicije naredil dostopne zavesti moralno uničene in $\mathrm{v}$ vsej njeni identiteti okrnjene povojne generacije. Skratka, je tako, kot da bi si ti intelektualci, ki jih je nacizem preganjal in izgnal, zelo prizadevali Nemcem rešiti njihovo kulturno identiteto: tako je z Adornom $\mathrm{v}$ Nemčiji spet postalo možno intelektualno, moralno in estetsko stopiti $\mathrm{v}$ korak $\mathrm{s}$ časom in pri tem vendarle ne sovražiti Kanta, Hegla, Bacha, Beethovna, Goetheja ali Hölderlina. Na ta način je Adorno bolj kot kdor koli drug prispeval k temu, da je sicer prepogosto rabljeni izraz 'drugačna Nemčija' prejel legitimni smisel. Njegovi konzervativni kritiki tega do danes niso dojeli." (Wellmer, 1993, 225) Vsekakor je dojel Habermas in mnogi ga danes želijo razvrednotiti, očitajo mu, da je filozof stare Zvezne republike Nemčije, ne pa te, združene, s prestolnico v Berlinu. Pravijo, da ga je sicer treba spoštovati, ne pa »več poslušati«. (Reemtsma, nav. iz Habermas, 2001, 35)

\section{Dialektika - napor vsebine}

Delo Theodorja W. Adorna $\mathrm{z}$ naslovom Minima Moralia je izšlo prevedeno v slovenski jezik leta 2007. Iz celotne naravnanosti tega dela izhaja, da se Adorno zaveda, kako izraz »morala « spremlja določeno nelagodje, ki ga je v novejši dobi temeljito zaznal Friedrich Nietzsche, kajti morala naj bi pomenila refleksijo o pravilnem življenju, tistem, ki uravnava pravilno življenje kot norma in posameznika celo poučuje, kaj da in česa ne. Na podlagi tega miselnega motiva je nastalo Adornovo delo Minima Moralia, izdano po drugi svetovni vojni, leta 1951. Pisano je bilo med drugim tudi kot nekakšna miniaturna kritika, ugovor in teoretska protiutež Aristotelovemu delu Magna Moralia. 
Adornovo delo spremlja zavest o tem, da življenje ne živi, kajti subjekt je izkusil vso ničnost in izgubo svoje avtonomije po koncentracijskih taboriščih. Zato ne preseneča tale uvodni zapis: „Žalostna znanost, katere drobec ponujam svojemu prijatelju, se nanaša na tisto področje, ki je od davnih časov veljalo za področje filozofije, odkar pa se je ta preobrazila v metodo, je zdrsnilo v intelektualno omalovaževanje, sentenciozno samovoljo in navsezadnje, pozabo: nauk o pravilnem življenju. Kar je nekoč za filozofe pomenilo življenje, je postalo sfera zasebnega in potem zgolj še porabe, ki se brez avtonomije in brez lastne substance vleče kot privesek materialnega proizvodnega procesa.« (Adorno, 2007, 7)

Kako se izogniti cinizmu v soočenju z zdajšnjim in s preteklim trpljenjem, saj ne premoremo niti besede, ki bi ga zmogla v zadostni meri izraziti? Kdo je tisti, ki bi to lahko? Gotovo, da ne kakšna »dobrodelna hijena" ali važič, ki na govorniškem odru kot slavnostni govornik ljudi spravlja v solze. Zgodovina 20. stoletja je zgodovina neizmernega pekla trpljenja in celo pojem je ranjen v soočenju ob misli na te, ki so umrli nepokopani, nas opozarja Adorno. Po Adornu ne moremo misliti kaj humanega (človečnosti) »z identifikacijo, temveč z njeno odsotnostjo «, in iz tega izhaja, da je »distanca kot medij spoznanja«. (Adorno, 1999, 273) Pristop, ki ga Adorno pri tem uporablja, je filozofski, kajti ne glede na to, o čem piše Adorno, razmišlja in zapisuje kot filozof - tudi takrat, ko nam postavlja vprašanje, zakaj je predpisana moralnost, vladajoča še posebej, porajala ogromno kriminalnosti in zakaj je malomeščanščina lahko vir totalitarizma.

Upor proti idealizmu in njegovemu olepševanju je več kot upravičen in možnost dati trpljenju, da spregovori, je nekaj, kar filozofija in z njo vred celotna humanistika mora narediti. Skratka, človečnosti oziroma humanosti sploh ne uspemo dojemati (misliti) več drugače kot samo $\mathrm{v}$ njuni odsotnosti, nenavzočnosti, ki vsakemu tradicionalnemu nauku o dobrem ali celo kakšnem najvišjem dobrem izrazi, da ga po Auschwitzu ne moremo več misliti. Tudi pojma pravilnega življenja ne smemo odtegniti temu, kar se je dogajalo na podlagi industrije smrti. Tako je v kantovskem smislu Auschwitz »zgodovinski znak« trpljenja v zgodovini, Adorno v svojem delu Metafizika uporablja celo pojem "relevanca znotrajčasovnega «, (Adorno, 1998, 159) ko milijoni pobitih in umorjenih opozarjajo na svoje nepokopano trpljenje.

$\mathrm{H}$ konceptu njegove filozofije spada, da prisluhne trpljenju, ki je tako zelo zaznamovalo zgodovino, in zato si je povsem prisvojil Platonovo kategorijo spomina, to je mnemosýne; po Adornovi trditvi jo je Platon celo »imel za živec filozofije«. (Adorno, 1976, 167) Zgodovinski spomin (Eingedenken) na trpljenje in dejstvo, kako je bilo filozofsko mišljenje skoraj sovražno razpoloženo do pojma sreče ali se ga je celo sramovalo, ga pripelje do tega, da se poistoveti s tisto »tradicijo filozofskega 
civilnega poguma «, (Adorno, 1976, 167) ki vodi nekako od Fichteja do Nietzscheja in ki bolečino in trpljenje izgovarja, izpoveduje, četudi pri tem še kako oporeka temu ali onemu filozofu, npr. Heideggerju, in kar vse tudi njemu samemu povzroča trpljenje. In ravno ta, zgodovinski spomin s svojo izrazito materialistično zarezo pripelje Adorna, da kot materialist govori o odrešenju in mesijanski luči, ki je po njegovem ni in je ne more biti na oni strani zgodovine.

Glede trpljenja ostaja za Adorna vprašanje, kako naj se filozofija sooča z njim, saj je iz programskega zapisa v uvodu Negativne dialektike "potreba dati trpljenju spregovoriti pogoj vsake resnice«, (Adorno, 1973, 29) v zaključnem delu Negativne dialektike pa, da je takó še metafizika »berljiva konstelacija bivajočega«. (Adorno, 1973, 399) Tako je nemški tradiciji očital ogabnost zaradi njenega priseganja na teodicejo zla in smrti. Adorno se nikakor ni strinjal s ponotranjanjem trpljenja, kot z nečim zelo globokim, zato je že njegov uvodni del Filozofske terminologije zelo odločna kritika pojma globine. Solidarnost s trpljenjem v smislu "poveličevanja samega trpljenja « (Adorno, 1976, 170) od filozofije in teologije, negovanje kulta žrtve po vzoru mitologije, povzročata pri Adornu en sam protest in zaradi tega zgodovini filozofije očita, da je »negacijo sreče povzdignila v metafizično substanco«. (Adorno, 1976, 172) Vsa ta dejstva so pripeljala do tega, da je še celo materialistično usmerjena filozofija sramežljivo izgovarjala pojem sreče, če ga sploh je.

Kako se je moglo zgoditi, da sta filozofija in vsa kultura gradili na paradigmi oplemenititi trpljenje in za ideal postavljati celo odrekanje sreči? Premoč obstoječega je filozofija s filozofskimi sredstvi podaljševala do njegove očitne apologije in s tem je postulat globine postajal ideologija. Na filozofijo je Adorno naslovil kar najstrožjo zahtevo prekiniti s táko identifikacijo in samó iz tega upora "preživi spekulativni moment: da si ne pusti predpisovati svojega zakona $\mathrm{z}$ danimi dejstvi, jih transcendira še v najtesnejši zvezi s predmeti in v odpovedi sakrosanktni transcendenci«. (Adorno, 1973, 29)

Nov, spremenjeni odnos filozofije do tradicije, ki naj mišljenje reši pred prekletstvom neposrednosti, je Adorno opisal z izrazom »metheksis filozofije«, (Adorno, 1973, 64) saj skuša povsem na novo razmisliti deležnost filozofije, ne samo na tradiciji, ampak še na celoti bivajočega, in to s pomočjo pojma določene negacije. Gre za anticipacijo odprave mišljenja, ki je ujeto v postvarelo danost, zato: »Metheksis filozofije na tradiciji bi bila edino njena določena negacija.« (Adorno, 1973, 64) Zelo sumljiva, in to celo med najbolj sumljivimi, je po Adornu vez med filozofijo in teologijo, kadar gre ravno za trpljenje. S tem da je filozofija s svojimi pojmi sublimirano ponavljala in obnavljala »teološko predstavo o absolutnosti božanskega principa « in ta princip sprejela celo za svojega, je sama "postala teodiceja trpljenja». (Adorno, 1976, 170) Vrhunec vsega tega 
razvoja je Adorno prepoznal pri Heglu, v njegovem pojmovanju zgodovine, ki naj bi bila organ resnice, in v njegovem pojmu zgodovine kot napredku je ena sama totaliteta trpljenja. Še posebej estetiki je očital prevzem tega motiva tragičnosti, ki je, vsaj kar se tiče nemške tradicije, postal prevladujoč literarni motiv.

Vsa načela tradicionalne morale so bila izničena in so popustila pod pritiskom fašizma, ki je počistil še $z$ zadnjim zavetjem tistega življenja, ki se je oklepalo česa etičnega, čeprav samo v notranji emigraciji. Zato aforizmi, zbrani v Minimi Moraliji, učinkujejo kot sila protesta, ki se je preselil v individuum. Ena sama resnica kot neresnica oziroma laž je totalno obvladovala življenje vseh in vsakogar. Adorno je moral emigrirati v Ameriko, da si je rešil življenje, podobno kot mnogi drugi, in uteči strašni usodi Petra Suhrkampa (1891-1959), ki je preživel koncentracijsko taborišče, ali še bolj tragičnemu dejanju Walterja Benjamina (1892-1940), ki si je v strahu pred gestapom raje prerezal žile, kot da bi mu padel v roke.

Čas po nastopu nacizma leta 1933 je bil za Adorna zelo naporen. Najprej je odšel v Anglijo, kjer je na univerzi v Oxfordu želel dokončati svoj doktorat o filozofu Edmundu Husserlu; delo je bilo objavljeno leta 1956 pod naslovom Zur Metakritik der Erkenntnistheorie. $\mathrm{V}$ tem času nastajajo tudi Adornove študije o sociologiji in glasbi; njegovi biografi posebej opozarjajo na odklonilen odnos do jazza, ki je trajne narave. Leta 1937 se je v Londonu poročil z Gretel Karplus, ki jo je spoznal že leta 1923, in vez je ostala trajna, (Boeckmann, nav. iz Müller-Doohm, 2007, 335-352) vendar trajnost $\mathrm{z}$ mnogimi soočenji tudi zelo boleče osebne narave in obojestranskega trpljenja.

Adorno se je z ženo 1938 najprej naselil v New Yorku, kjer je bil skupaj z Maxom Horkheimerjem sodelavec Inštituta za družbene raziskave. Po dveh letih ne ravno uspešnega sodelovanja sta se z ženo preselila v Los Angeles, še pred tem tudi Max Horkheimer skupaj z ženo Rose Christine Riekher, ki jo je imenoval Maidon. Tu je nastopilo Adornovo ameriško obdobje, ki ga je prebil v Kaliforniji v letih 1941-1949. Čas, ki ga je Adorno preživel v Ameriki, v New Yorku in pozneje Kaliforniji v Los Angelesu, ni bil sterilen, nasprotno, bil je izjemno produktiven. Dela, ki so nastajala v tem času, so celo svetovno odmevna, skratka, to obdobje je bilo zanj zelo uspešno in v njem je bil dejaven. Vrsta objavljenih del kaže na to dejstvo in celotno bivanje v Obljubljeni deželi je dokaz o njegovi izjemni ustvarjalnosti, ki jo je še najlažje opisati z njegovim opozorilom, da je sreča mišljenja v tem, če lahko vsak trenutek razmišlja, $\mathrm{v}$ še tako težkih razmerah in na robu preživetja. Mislim, torej lahko preživim, in če razmišljam, potem zares sem in se ohranjam. Filozofija nima nikjer prepovedi, saj gre pri njej za mišljenje sámo, ki mora ostati dejavno; misliti vsak trenutek, še v najbolj brezupnem stanju, v tem je po Adornu celo sreča mišljenja. 
Kakršna koli je že Adornova sodba o Ameriki, ena najpozitivnejših je gotovo ugotovitev, ki jo je podal leta pozneje, ko je ponovno analiziral trajni učinek svojega bivanja v Ameriki na svojo dejavnost, da je »verjetno moč rezistence do fašističnih gibanj v Ameriki večja kot v kateri koli evropski deželi, z izjemo morda Anglije«, (Adorno, 1977, 735) čeprav poudarja, da ne izključuje možnosti nastopa kakšnega totalitarizma tudi v ameriških razmerah. ${ }^{1} \mathrm{Na}$ svoji koži je čutil sprevrženost pojma svobode, ki »na koncu pomeni pravico močnejšega in bogatejšega, da šibkejšemu in revnejšemu odvzame še tisto malo, kar ima«. (Adorno, 2007, 286) Od tod njegovo odločno odklanjanje liberalizma, ki mu kot talilnemu loncu namenja tele besede: »Melting pot je bil izmislek $\mathrm{z}$ vajeti spuščenega industrijskega kapitalizma. Misel na to, da se znajdemo potopljeni vanj, priklicuje mučeniško smrt, ne pa demokracije.« (Adorno, 1977, 113)

V delu Knjiga mrtvih filozofov avtor v dokaj lahkotnem stilu opisuje Adornovo bivanje v sončni deželi na zahodu Amerike, v Brentwoodu v zahodnem Los Angelesu, bogatem in luksuznem naselju: »Med decembrom 1941 in oktobrom 1949 sta Adornova prebivala v udobni hiši na South Kenter Avenue, samo za met noža od kraja, kjer je O. J. Simpson 'domnevno' umoril svojo nekdanjo ženo.« (Critchley, 2014, 291-292) Slavna imena, zbrana v luksuznem okolju, v katerem so bivali takrat nekateri znani nemški intelektualci, med njimi tudi Thomas Mann s soprogo - in Mann se je pri nastajanju svojega romana Doktor Faustus večkrat posvetoval z Adornom. (Gödde, Sprecher, 2002, 155-161) Skupaj sta Adorno in Horkheimer napisala Dialektiko razsvetljenstva, eno najbolj izstopajočih filozofskih del v 20. stoletju, ki je izšlo šele po vojni, leta 1947. Med drugim je Adorno v tem kalifornijskem obdobju napisal glavnino teksta Minima Moralia, v katerem mu je uspelo v zelo zgoščeni, aforistični obliki zavidljivo združiti spontanost in avtonomijo mišljenja.

Teddy, kakor so Adorna imenovali prijatelji, je navezal stike s holivudsko druščino igralcev in med njimi bi naj bi bila celo Greta Garbo. Filmske lepotice Adorna niso pustile ravnodušnega, imel naj bi celo vrsto erotičnih zgodbic, »serijo ljubezenskih avantur «, (Critchley, 2014, 292) kar omenja le malo Adornovih biografov. Morda je nekaj malega v tem smislu izrazil sam Adorno, ki je sicer ostajal Gretel zvest; njuno kalifornijsko obdobje naj bi veljalo celo za srečno. V Minimi Moraliji, in sicer v tretjem delu, datiranem z 1946-1947, zato ne preseneča aforizem Svarilopred zlorabo:»Dialektik pozna nesrečo in zapuščenost tistih, ki se starajo neporočeni, pozna morilskost ločitve. Toda s tem ko prav nič romantično daje prednost realizirani zakonski zvezi pred bežno strastjo, ki se v skupnem življenju ne ohrani, postane zagovornik tistih, ki ostajajo v

1 Recimo kot so bila koncentracijska taborišča v ZDA med drugo svetovno vojno - sicer brez mučenj in pokolov - za Američane japonskega rodu (110. 000), za Američane nemškega rodu (11.000) in za Američane italijanskega porekla (3000). 
zakonu za ceno naklonjenosti, ki ljubijo tisto, s čimer so poročeni, torej abstraktno lastniško razmerje.« (Adorno, 2007, 281)

Pravilno življenje kot zakon moža in žene bi bil po Adornu kaj? Že skoraj pol stoletja je od njegove smrti in morda marsikaj ni več up to date, toda Adornovega razmisleka o dostojnosti zakona kot življenja v dvoje iz leta 1944 ne moremo prezreti, saj ga izrecno povezuje $z$ načelom svobode: »Dostojen zakon bi bil šele tisti, v katerem bi oba živela svoje lastno neodvisno življenje, brez zlitja, ki izvira iz ekonomsko izsiljene interesne skupnosti, in bi svobodno prevzela nase medsebojno odgovornost drug za drugega.« (Adorno, 2007, 27) Le kdo bi temu oporekal?

Kako živeti v svetu, ki je tetoviran, trajno zaznamovan z Auschwitzem, v času »po metafiziki«, o katerem Habermas s pomočjo Adornove Minime Moralije in njenega »melanholičnega refrena na Nietzschejevo veselo znanost « ugotavlja, da »si filozofija ne upa več odgovarjati $z$ odgovori na vprašanja o tem, kakšno naj bo osebno ali celo kolektivno življenje«, in se zato tudi že z naslovno formulacijo sam sprašuje, »če obstajajo pometafizični odgovori na vprašanje o 'pravilnem življenju' «? (Habermas, 2009, 11)

Ne samo življenje posameznika, ki je po letu 1933 moral emigrirati, da si je sploh rešil življenje, tudi knjige so trpele, tudi one so doživele to, kar Adorno v delu Minima Moralia v podnaslovu imenuje poškodovano, to je okrnjeno življenje. Pri tem piše esejistično, tako da si esej po Adornu pomen besed prisvaja po vzoru tistega, ki jih v tujini brez ustreznega znanja jezika skuša razumeti kar najbolj neposredno, namreč »brez slovarja«; vsak posamičen pomen je prepuščen gibanju, ki pojme odteguje vsakršni "normi etabliranega mišljenja«, (Adorno, 1999, 15) nesporne in enoznačne gotovosti. S tem esej ohranja nekaj dragocenega, to je utopično naravnanost.

V eseju Bibliografske muhe iz leta 1956, objavljenem skupaj z drugimi eseji v delu Beležke o literaturi III, je spregovoril še o trpljenju knjig, ki jih je jemal s seboj na pot, kamor ga je pač zaneslo, v London, New York, Los Angeles, in emigracija tudi njim ni prizanesla. Knjige so se poškodovale, strani in platnice so se odlepile, vendar razpadajočih ni pustil propasti. Zlepil jih je, sproti dal popravljati in spet so romale $\mathrm{z}$ njim in se vrnile nazaj v Nemčijo, toda nič se ni z njim vrnilo nepoškodovano. Nekdanje razpadle knjige so po Adornovi vrnitvi v Nemčiji kot zlepljene oživele in kot brošure doživele svojo drugo mladost. Zdaj so kot »minljivi dokumenti enovitosti življenja, ki se jih oklepa, in obenem njegovih prelomov, ob vsej naključnosti rešitve in tudi s sledjo nedoumljive previdnosti v tem, da se je to ohranilo, ono bilo zapravljeno«. (Adorno, 1999, 239) Torej imajo tudi knjige svojo usodo trpljenja, ki je zaznamovalo subjekte stoletja, ki je bilo eno najbolj zasvojenih stoletij s politiko. In če Adorno knjigam zavida zmožnost druge mladosti, je pri človeku verjetno stvar povsem drugačna. Kako naj regenerira nekaj poškodovanega, ko gre za človeške usode? 
Adorno v eseju Angažma navaja Sartrove besede iz dela Nepokopani mrtveci: "Ali ima življenje smisel, dokler so na svetu ljudje, ki te bijejo tako dolgo, dokler ti ne polomijo kosti.«(Adorno, 1999, 289; Sartre, 1960, 247) Temu sledi Adornovo protivprašanje: »Ali umetnost sploh še sme obstajati; ali regresija same družbe ne zapoveduje duhovne regresije v pojmu angažirane literature?«(Adorno, 1999, 289) Cinizem ni pravi odgovor, tudi ne ignoranca, s katero se je povojna Nemčija soočila $\mathrm{z}$ dejstvom Auschwitza. Adornovo odločno in načelno stališče je tole: »Presežek realnega trpljenja ne trpi pozabe.« (Adorno, 1999, 289) Adornovo soočenje s trpljenjem spremlja etika dosledne prepovedi pozabljanja trpljenja.

Kako torej? Njegovi negativni dialektiki kot »dosledni zavesti o neidentiteti« (Adorno, 1973, 17) in hkrati kot "nereduciranemu izkustvu $\mathrm{v}$ mediju pojmovne refleksije« (Adorno, 1972, 25) mora uspeti izpovedati resnico o tem najbolj bolečem, torej samo o neposrednem, konkretnem življenju in njegovih najbolj temnih podobah odtujitve hkrati z vsem objektivnim, kar je subjekte določalo do vseh potankosti kot $\mathrm{v}$ sebi odtujene. Tudi pogled na neposredno stanje in razmere se je spremenil videologijo in "prikriva, da življenja ni več«. (Adorno, 2007, 7) Smo si torej ideologije izmislili zato, ker smo z njimi življenje devitalizirali tako daleč, da nas samo še kak Friedrich Nietzsche strezni in napoti v bistveno drugačnost, ki že domala vpije "pojdi stran od vsega, kjer ni več življenja«. Tudi naš humanizem je načet, kajti v njegovi duši »razsaja ujet divjak, ki kot fašist spreminja svet v zapor «, (Adorno, 2007, 96) zato človeku, ki piše, kratijo pravico, da bi prebival v svojem pisanju. Kot da bi bil aforistični način pisanja še najbolj ustrezen odziv na stanje, kjer "primanjkuje možnosti za veselje« in se življenje reducira na »razkazovanje, golo pripadnost «, v »dolgočasju coctail parties« (Adorno, 2007, 213-214) in igranju golfa ob koncu tedna. Ideologijo tega sveta Adorno opisuje s temle: "Zloba zgornjega sloja - ta se tako ali tako demokratizira - nazorno razkriva, kar za družbo že dolgo velja: življenje je postalo ideologija svoje lastne odsotnosti.« (Adorno, 2007, 212)

Ne samo fašizem, tudi liberalizem je slaba popotnica vživljenju, ki biva osiromašeno. Življenje je namreč posurovelo in je ravno tako poškodovano, kajti načelo konkurence je načelo hudega redukcionizma. Uči nas, da vse merimo, in kot izmerjeno obvelja za mero presoje o tem, kaj da in kaj ne. Urejenost knjig na policah je zoprna, ker nam nič ne pove o subjektu, ki jih poseduje, in Adorno v življenju knjig vidi nekaj, kar spominja na njegovo lastno življenje, kajti knjige se redu upirajo in tako "vztrajajo na mestih, ki si jih same izberejo«, so kot »neudomačene domače živali«. (Adorno, 1999, 239-240) Morda zato, ker njihovega trpljenja ne moremo nikdar udomačiti.

Je etika nekaj, kar nam omogoča, da smo v določenem trenutku celo solidarni z nečim, kar je dejansko zločin, čeprav vemo, da gre za povsem napačno stvar in da 
nismo nič storili proti temu? V prispevku z naslovom Moralnost in kriminalnost prvotno je bil objavljen v Spieglu 5. avgusta 1964 ob ponovni izdaji istoimenskega dela Karla Krausa - poudarja neko zelo določeno aktualnost dela. Ta po Adornu ustreza svetu meščanske družbe, ki se je hudobno »obdala $\mathrm{z}$ zidom, kot da bi bila po naravnem zakonu tako večna, kot je to od nekdaj pozitivno zatrjevala v svoji ideologiji. Še vedno jo zaznamujeta otrdelost srca, brez katere nacionalsocialisti ne bi mogli nemoteno pomoriti milijonov, in vladavina principa menjave nad ljudmi, razlog tiste subjektivne otrdelosti.«(Adorno, 1999, 252)

Etika torej, ki dopušča kriminalnost, čeprav v zelo prikriti obliki, kajti kot poudarja Kraus, te misli navaja tudi sam Adorno, gre za tole: »Kazenski zakonik je družbena zaščitna ureditev. Bolj ko je država kulturna, bolj se bodo njeni zakoni bližali nadzoru družbenih dobrin in se oddaljevali od nadzora individualnega notranjega življenja.« (Adorno, 1999, 252-253) O tem nasprotju Adorno pove, da je to celo antagonizem celote, in Krausova knjiga povzema v bistvu to dejstvo, kajti: »Moralnost, vladajoča, veljavna tu in zdaj, proizvaja kriminalnost, postaja kriminalna." (Adorno, 1999, 253) Etika je tako represivni sistem in v aforizmu Protislovja v končnem delu Dialektike razsvetljenstva, posebej naslovljenem kot Zapiski in osnutki, Adorno ogorčeno ugotavlja: "Morala kot sistem, z načeli in izpeljavami, z železnim sklepanjem, zagotovljeno uporabnostjo v vsaki moralni dilemi - to je tisto, kar se zahteva od filozofov. Pričakovanje so praviloma izpolnili.« (Horkheimer, Adorno, 2002, 262) Skratka, ne samo cinizem, ampak izrecno kriminal, zato je Krausovo delo po Adornu postalo popularno s tole mislijo: »Moralni proces je smotrni razvoj individualne nemoralnosti v splošno nemoralnost, od katere mračnega temelja se izkazana krivda obtoženca bleščeče odbija.«(Adorno, 1999, 253) Prenos krivice in razlikovanja, ki ponotranja logiko gospostva, samokontrolo, to je ukazujoče sebstvo na etiko, je samo eno, in to etika kot represija in tiranija dobrega. Od tod je treba razumeti Adornovo averzijo do tradicionalne etike, ne pa do etike kot take, in znana anarhoidna levičarska teza, da je vsaka etika sinonim za represijo, v Adornu ne more imeti svojega guruja.

\section{Možnost za metafiziko po industriji smrti}

Po petnajstih letih emigracije, oktobra leta 1949, se je Adorno vrnil nazaj v svoj rodni Frankfurt, kjer je bilo vse razrušeno, uničeno, in začeti je bilo treba znova. Rektor univerze v Frankfurtu, ki nosi ime po Goetheju, je postal Max Horkheimer, Adornov mladostni sodelavec in po letu 1933 prav tako emigrant. Vendar je zdaj njuno bivanje in delovanje na univerzi v Frankfurtu zaznamovano $\mathrm{z}$ očitki, da sta radikalna levičarja, kar je v povojni antikomunistični Adenauerjevi Nemčiji seveda pomenilo biti komunist, to pa je bila psovka. 
Poškodovano in okrnjeno življenje - s čim je zaznamovana ta refleksija? Z bolečino, trpljenjem, holokavstom milijonskih razsežnosti in zato ni razmer, da bi nastala kakšna vesela znanost - sicer Nietzschejev izraz - s še bolj veselim oznanilom. Ne samo, da je Auschwitz bil, komaj dobrega pol leta po tem, ko je bil januarja 1945 leta osvobojen, mu je sledila še Hirošima. Danes je treba reči, da je bil tudi zdaj že vsekakor simbolni 11. september 2001, ob katerem smo vsi bili njegovi nemi opazovalci in ob katerem je vsak poznavalec Adornove misli moral doumeti smisel njegovega pojmovanja zgodovine, $s$ katerim je opozarjal, da je zgodovinski razvoj zelo alternativen. Ne moremo govoriti samo o kontinuiteti, ampak tudi o diskontinuiteti, ne samo o napredku, temveč tudi o zgodovinskem razvoju kot permanentni katastrofi, o možnosti padca nazaj v barbarstvo.

Dejstvo industrije smrti po številnih koncentracijskih taboriščih ali kar z zbirnim izrazom fenomen Auschwitz je Adornovo misel trajno zaznamovalo. Nekaj podobnega lahko vidimo samo še pri Platonu, na katerega je učinkovala Sokratova smrt. Po tej plati tako Platon kot Adorno dokazujeta, da je eden od najmočnejših vzgibov za filozofijo (in še posebej za metafiziko) človekovo soočenje s smrtjo. Kdor se je vsaj malo izšolal s pomočjo Adornove misli, ostaja temu trajno zavezan, kot v najnovejšem času eden najbolj znanih Adornovih učencev Peter Sloterdijk, ki mu je kot enemu redkih, če že ne edinemu, ponekod uspelo »spraviti« dva nespravljena misleca, namreč Heideggerja in Adorna. Pri tem je Sloterdijk v svoji Kritiki ciničnega uma zapisal o terorju kot konsekventnem idealizmu, da ta od filozofa zahteva celo določeno predrznost. Smisel te predrznosti je v temle: V kulturi, v kateri utrdeli idealizmi napravijo laž za življenjsko obliko, je proces resnice odvisen od tega, ali se bodo našli ljudje, ki so dovolj agresivni in svobodni ('nesramni'), da povedo resnico.«(Sloterdijk, 2003, 126)

Filozofirati po Auschwitzu in razmišljati o možnosti za metafiziko, ki je bila paralizirana zaradi smrti milijonov, je kot neizrekljivo, in Adorno je od filozofije in celotne humanistike pričakoval, da ji bo za začetek uspelo izreči vsaj to, kako je laž učinkovala kot resnica in resnica kot laž. Prevarantstvo kot totalna moč razpolaganja nad ljudmi in stvarmi je po Adornovem uvidu pripeljalo do stanja, ko ni samo zabrisana razlika med resnico in lažjo, ampak ko ima samo še absolutna laž »svobodo, da sploh izreče kakšno resnico«. (Adorno, 2007, 119) Sprememba vseh vprašanj resnice $v$ vprašanje moči ne samo da zatira resnico, ampak pripelje do tega, česar prejšnji represivni sistemi pred fašizmom in nacizmom niso poznali, namreč zabrisana je razlika med tem, kaj je prav in kaj je napačno.

Če izhajamo ne iz vprašanja, kaj ima nam ponuditi Adornova misel danes, ampak obratno, kaj imamo mi pokazati njej, potem seveda njegovo delo Minima Moralia zelo zgovorno opisuje proces porajanja nečesa represivnega s temi besedami v 123 . aforizmu z zelo značilnim naslovom Hudobni tovariš: »Pravzaprav bi moral fašizem 
znati izpeljati iz svojih spominov na otroštvo. Tako kot zavojevalec daljnih pokrajin je fašizem tja vnaprej poslal svoje glasnike, dolgo pred tem, ko je sam vkorakal: moje šolske tovariše.« (Adorno, 2007, 217) Z neko prefinjeno, samo Adornu lastno senzibilnostjo spregovori o tem, kako ga je tretji rajh sicer neprijetno presenetil glede njegove politične presoje, ne pa glede njegove «nezavedne pripravljenosti na strah«. (Adorno, 2007, 217) Kot da bi odraščal z motivi, ki so pripeljali do zla, kajti že šola je bila institucija, kjer so na grozljiv način vsi zatirali vsakega: » $V$ fašizmu je nočna mora otroštva postala realnost. (Adorno, 2007, 218) Je bila torej fašizacija sveta med drugim možna zaradi naše vzgoje, ki nas je naredila vse preveč dovzetne za agresivnost, najprej proti nam samim in nato še proti drugim? Kako je $\mathrm{z}$ agresivnostjo danes, recimo to, ki jo vidimo že po šolah? Treba je tudi upoštevati, da je kapitalizem vedno nevarna bližina fašizma.

V represivni družbi sta »svoboda in nesramnost eno in isto «, (Adorno, 2007, 120) opozarja Adorno. Najbolj zgovoren dokaz tega je manifestacija svobode zdajšnjega sveta v podobi komolčarstva, ki se hkrati kaže še kot razkriti mehanizem tekmovalnosti in konkurence. To načelo smo po letu 1989, odeto v najbolj kičaste cape demokracije, belino kalodontnega nasmeška in polakirano s pojmom tolerance, sprejeli kot protiutež pojmu solidarnosti.

Materialistična zareza skozi celoten svet je človeštvu pomagala izoblikovati takšen pojem sveta, v katerem naj ne bi bilo več strahu, bede, lakote in gospostva - takšnega ali drugačnega. Tisto $\mathrm{v}$ materializmu največje in najbolj prepričljivo je po Adornu to, da je doumel, kako je za dosego dejanske svobode nujno materializem ukiniti - v nekem zelo določenem pomenu. Vprašanje o svobodi se bo zares postavljalo namreč šele tam, kjer bodo vse materialne prisile odpravljene. Mojo generacijo 68, ki je študirala s pomočjo Adornove misli in skušala doumeti, da je mišljenje protiprodukcija, "proces razreševanja konkretnosti v sami sebi«, in dialektika "vselej razkraja tudi sámo razkrajajoče» (Adorno, 2007, 279) in se pri tem ne sklicuje na nič "prvega« in tudi ne "poslednjega«, spremlja dejstvo, da se svet ni znašel onkraj kapitalizma in komunizma, ampak krepko $\mathrm{v}$ kapitalizmu neoliberalistične provenience. S tem dejstvom je bila soočena slovenska izdaja prevoda knjige Minima Moralia.

Nismo se odrekli upanju, utopiji, metafiziki, tudi ne solidarnosti, samo da $\mathrm{z}$ Adornovo pomočjo ta trenutek vemo, da »je za intelektualca neomajna samota edino obličje, v katerem nekako še lahko pokaže solidarnost. Vse sodelovanje, vsa človeškost druženja in udeležbe so gola maska za molčeče sprejemanje nečloveškega. Človek bi moral deliti trpljenje s soljudmi: najmanjši korak $\mathrm{k}$ njihovim radostim je korak $\mathrm{k}$ otrdelosti trpljenja." (Adorno, 2007, 21) Kot da bi bil edini smiselni protest samo še ta, ki se je preselil v našo notranjost, saj navzven ta trenutek ne moremo delovati. Bivanje s 
takim notranjim protestom je po svoje prijetno, kajti čutiš silo, ki to omogoča, da se ne izgubljaš v nepravem svetu, da nisi eno z njim, zdaj, ko nismo več mladi.

Kljub Auschwitzu, ki je »paralizirana zmožnost za metafiziko«, (Adorno, 1973, 354) še negujemo metafizično zmožnost, da na stvareh in dejstvih dojemamo nekaj več kot samo to, kar one so, upanje, da bi lahko bilo drugače, bistveno drugače, kot je. Danes levi optimizem ne vpije več tako kot $\mathrm{v}$ Adornovem času: če komu svet ni všeč, naj si poišče boljšega. To bi bilo, verjetno tako po malomeščansko in salonsko levo, klicanje hudiča zdaj, ko jih imamo že krepko čez šestdeset, smo se odločili za tempelj miru.

Adorno je med prvimi nemškimi filozofi tematiziral misel o industriji smrti, o dejstvu holokavsta, ki si še danes mukoma utira pot v našo, slovensko kulturo in ki ga je tudi povojna nemška kultura ignorirala in ob njem molčala. Upal si je spregovoriti, kajti nikakršna etika molka ni pravi odgovor na to, kar se je dogajalo z ljudmi po koncentracijskih taboriščih. Teorija mora znati spregovori tudi tam, kjer najbolj boli, in najti govorico za milijone žrtev, ki so neme. Ta strašna logika identitete, ki je pomorila na milijone ljudi, se je dogajala v svetu, ki je sebe štel za naslednika velike starogrške kulture.

Ne samo, da je smrt postala nekaj brezosebnega; ponižana in zgažena je bila ideja nesmrtnosti, tudi kultura sama se je sesula sama vase zaradi očitnega pregona ideje nesmrtnosti. Kako se je vse to lahko zgodilo in zakaj, to sta vprašanji, ki Adorna nista nehali spremljati vse do njegove smrti.

\section{Bibliografija}

Adorno, T. W., Beležke o literaturi, Ljubljana 1999.

Adorno. T. W., Kulturkritik und Gesellschaft I, GS 10.1, Frankfurt am Main 1977.

Adorno, T. W., Metaphysik. Begriff und Probleme, Frankfurt am Main 1998.

Adorno, T. W., Minima moralia. Refleksije iz poškodovanega življenja, Ljubljana 2007.

Adorno, T. W., Negative Dialektik, GS 6, nav. v: Adorno, T. W., Gesammelte Schriften (GS) 1-22 (ur. Tiedemann, R.), Frankfurt am Main 1973.

Adorno, T. W., Noten zur Literatur, GS 11, Frankfurt am Main 1974.

Adorno, T. W., Philosophische Terminologie. Zur Einleitung 1 (ur. zur Lippe, R.), Frankfurt am Main 1976.

Adorno, T. W., Uvod v sociologijo, Ljubljana 2016.

Adorno, T. W., Wissenschaftliche Erfahrungen in Amerika, nav. v: Adorno, T. W., Kulturkritik und Gesellschaft II, GS 10.2, Frankfurt am Main 1977.

Critchley. S., Knjiga mrtvih filozofov, Novo mesto 2014. 
Gödde, C., T. Sprecher (ur.), Theodor W. Adorno. Thomas Mann. Briefwechsel 1943-1955, Frankfurt am Main 2002.

Habermas, J., Die Zukunft der menschlichen Natur. Auf dem Weg zu einer liberalen Eugenik?, Frankfurt am Main 2009.

Habermas, J., Glauben und Wissen. Friedenspreis des Deutschen Buchhandels 2001, Frankfurt am Main 2001.

Horkheimer. M., Adorno, T. W., Dialektika razsvetljenstva: filozofski fragmenti, Ljubljana 2002.

Müller-Doohm, S. (ur.), Adorno-Portraits. Erinnerungen von Zeitgenossen, Frankfurt am Main 2007.

Sartre, J. P., Nepokopani mrtveci, Ljubljana 1960.

Schnädelbach, H., Philosophie in der modernen Kultur, Frankfurt am Main 2000.

Sloterdijk, P., Evrotaoizem. H kritiki politične kinetike, Ljubljana 2000.

Sloterdijk, P., Zorn und Zeit. Politisch-psyhologischer Versuch, Frankfurt am Main 2006.

Tóth, C. H., Dialektika refleksijskega zagona, Ljubljana 2015.

Tóth, C. H., Hermenevtika metafizike. Metafizika - materializem - etika - utopija, Ljubljana 2008.

Vattimo, G., Konec moderne, Ljubljana 1997.

Wellmer, A., Endspiele: Die unversöhnliche Moderne. Essays und Vorträge, Frankfurt am Main 1993. 


\section{Cvetka Hedžet Tóth}

\section{Anamnetični um}

Ključne besede: anamnetični um, mnemosyne, upanje, utopija, metafizika.

V zgodovini je bilo ogromno trpljenja in teorija je dolžna spregovoriti o njem; vsekakor je sramota zamolčevati to, kar pooseblja Auschwitz, namreč industrijo smrti - sramoto, za katero je soodgovorna tudi zahodna kultura, svari nemški filozof Theodor W. Adorno (1903-1969) v vseh svojih delih, pisanih po drugi svetovni vojni. Kako se soočiti z bolečino Auschwitza, zaradi česar je ranjena tudi večnost in ko je bila med drugim posamezniku kratena pravica do individualne smrti? Torej: kako negovati zgodovinski spomin, anamnetični um, um, ki ne pozablja, tj. mnemosyne po Adornu. Izgovarjati trpljenje, kazati nanj, biti solidaren z njim ni isto kot trpljenje poveličevati. Članek analizira Adornove nazore o tem, kako se je življenje ljudi po tej strašni izkušnji kolektivne smrti spremenilo in nam izoblikovalo celo nov kategorični imperativ, novo nujno obliko za preživetje: »Hitler je ljudem v stanju njihove nesvobode vsilil nov kategorični imperativ: njihovo mišljenje in ravnanje urediti tako, da se Auschwitz ne more ponoviti, da se ne more zgoditi nič podobnega. " Novega kategoričnega imperativa idealizem po Adornovi presoji ni zmožen udejanjiti. 


\section{Cvetka Hedžet Tóth}

\section{Anamnestic Mind}

Keywords: anamnestic mind, mnemosyne, hope, utopia, metaphysics

Our history has seen immense suffering and theory is more than obliged to speak about it. It is a true disgrace to fail to address what is personified by Auschwitz, namely the industry of death - a disgrace for which, according to Adorno in his after-war texts, our Western culture bears partial responsibility, too. How to face the pain of Auschwitz, which is also inscribed in eternity, when the individual was even denied the right to individual death? How are we to nurture historical memory, the anamnestic mind, the mind that does not forget (mnemosyne according to Adorno)? To speak about suffering, point our finger at it, express solidarity with it does not mean to glorify pain. The article analyses Adorno's views on how this horrific experience of collective death has forever changed our lives and even formed a new categorical imperative and a new form of survival: "A new categorical imperative has been imposed by Hitler upon unfree mankind: to arrange their thought and actions so that Auschwitz will not repeat itself, so that nothing similar will happen." And according to Adorno, idealism fails to enact this new categorical imperative. 